\title{
Når vi avslutter terapien - hva trenger vi da?
}

\section{Per Einar Binder}

Professor $i$ psykologi ved Universitetet $i$ Bergen

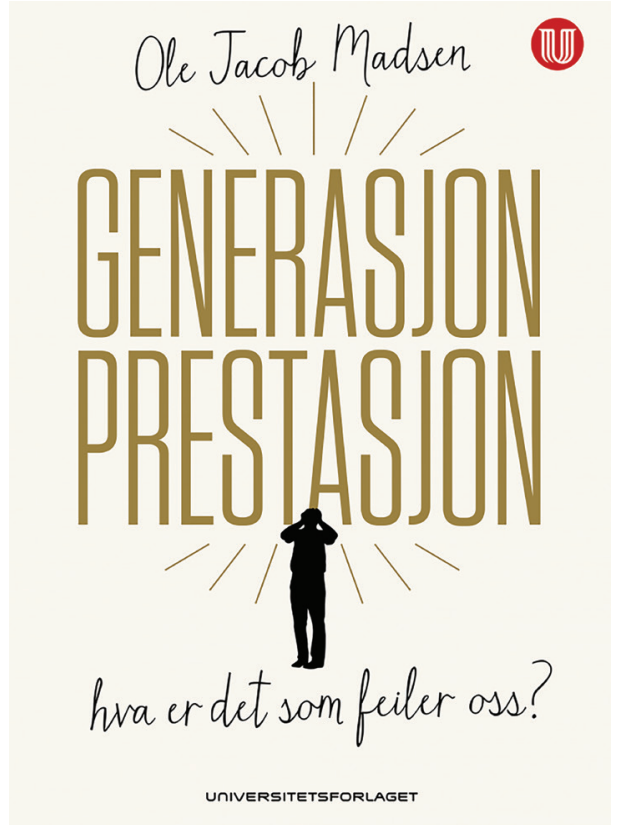

Ole Jacob Madsen: Generasjon prestasjon - hva er det som feiler oss? Universitetsforlaget, 2018, 240 sider

I boken «Generasjon prestasjon - hva er det som feiler oss?» undersøker Ole Jacob Madsen hvordan det terapeutiske og diagnostiserende språket psykologprofesjonen tilbyr ungdommen, reduserer deres selverkjennelse. Det begrenser både samfunnets forståelse av en ungdomsgenerasjon, og deres forståelse av seg selv. Livet som sådan er tidvis smertefullt. I tråd med Hackings imitasjons- og internaliseringsmodell og teori om selvfortolkninger påpeker Madsen at det diagnostiske ikke bare suggererer frem lidelse - det blir også et språk og et uttrykk for lidelse. Språk og lidelsesfortolkninger kan være både lukkende og frigjørende. For «generasjon prestasjon» kan terapi og diagnosespråket bli låsende. For alle de unge som ikke er spesielt

^Korrespondanse: Per Einar Binder, Det psykologiske fakultet, Universitetet i Bergen, Postboks 7807, 5020 Bergen. Epost: Per.Binder@uib.no.

(C) 2019 Per Einar Binder. This is an Open Access article distributed under the terms of the Creative Commons Attribution 4.0 International License (https://creativecommons.org/licenses/by-nc/4.0/), allowing third parties to copy and redistribute the material in any medium or format and to remix, transform, and build upon the material for any purpose, even commercially, provided the original work is properly cited and states its license.

Citation: Per Einar Binder. "Når vi avslutter terapien - hva trenger vi da?" Nordisk tidsskrift for pedagogikk og kritikk, Vol. 5, 2019, pp. 5-8. http://dx.doi.org/10.23865/ntpk.v5.1583 
prestasjonsorienterte, og som oftest er dem som virkelig strever med psykisk uhelse, så etterlater generasjonsdiagnosen et stort tomrom.

Forfatteren inntar først og fremst rollen som kritiker av den diagnostiske og terapeutiske diskursen. Og han lykkes godt med dette. Han tegner opp det bredere historiske og idemessige landskapet rundt vår tids ungdomsforståelse. Han går inn blant andre i Nietzsche, Weber, Fromm og Freuds problematiseringer av livet i moderniteten, og Ziehe, Beck og Baumans refleksjoner over senmodernitetens særegne menneskelige livsutfordringer. De løfter alle frem typer av "patologier» knyttet til samtiden, patologier som Madsen også etter mitt syn ganske riktig påpeker vil bli en del av vår selvfortolkning.

Madsen analyserer også det politiske landskapet rundt diagnostiseringen av ungdomstiden. Venstresiden har generelt sett den menneskelige lidelsen som samfunnsskapt. Forfatteren holder seg til den moderate venstresiden, og går ikke inn på de mer ekstreme uttrykkene for et slikt syn. Psykoterapi ble i Sovjetunionen generelt betraktet som et uønsket utslag av borgerlig individualisme, og ideen om at et perfekt samfunn kunne hindre nær ethvert menneskelig problem, var en bærende del av ideologien. Madsen antyder hvordan høyresiden tenderer til å se menneskelig lidelse som noe mer eksistensielt, og noe som også ligger innunder den enkeltes ansvar. Han går imidlertid ikke inn i den evolusjonsorienterte delen av psykologiens «høyreside», blant annet representert ved Stephen Pinker, som gjerne har vært mest toneangivende for kritikken av venstresidens ideer om det rent samfunnsskapte menneske. Pinker benytter i sin kritikk - i likhet med Jordan Peterson - Sovjetunionen som hoggestabbe.

Den noe større og polariserte debatten rundt samfunn og individforståelse blir noe Madsen ikke går videre inn $\mathrm{i}$. Dette er i og for seg naturlig, bokens overordnede problemstilling knyttet til generasjon prestasjon tatt i betraktning. Det blir likevel noe som gjør at en naturlig neste problemstilling blir hengende - hva skal alternativet til det psykologiserende og diagnostiserende perspektivet på lidelsen være? Gjennom mesteparten av menneskehetens historie har religionene ivaretatt forklaringsmodeller for den menneskelige lidelsenes mening. Lidelsens problem er den meningsbærende aksen for både Buddha og Jesus. Psykologien fikk sin store mulighet da det religiøse fortolkningssettet tapte terreng. Psykologen har i mange henseender tatt prestens plass. Å gå inn i de religiøse fortolkningene er fortsatt aktuelt for mange, men for det store flertallet av Vestens mennesker er religionene ikke fullt så aktuelle. Det vil også for de fleste oppleves utilstrekkelig å utelukkende beskrive sine individuelle livsutfordringer i et politisk språk, selv om det selvsagt både blir naturlig og riktig der marginalisering og vanskelige levekår er en viktig del av bildet. Når religionene og politikkens språk ikke gir gjenklang, og når det terapeutiserte språket blir lukkende og selvsentrerende - hva trenger vi da? Madsen trekker frem den eksistensielle tenkningen som en mulighet. Han påpeker også behovet for en moralsk diskurs i relasjonen mellom ungdom og foreldre, og at foreldre må kunne våge å stå for upopulære standpunkt. Han går dessverre ikke videre inn i dette rommet. 
Madsen er dyktig til å utfordre klisjeforestillinger gjennom spissformuleringer. Som han påpeker, oppfordres alle unge mennesker til å "snakke om det». De inviteres inn i en terapeutisk diskurs om livsutfordringer og følelsesliv. Fortsatt påpekes det stadig at gutter «snakker for lite». Men som han også påpeker, etter tiår med dette budskapet så beskrives ingen bedring hva gjelder ungdoms psykiske helse. Det hjalp kanskje ikke å «snakke om det». Tilsynelatende en viktig påpeking. Likevel savner vi å høre mer om: Hva bør vi da gjøre? Bør ungdom oppfordres til å begynne å tie om det? Homo sapiens har alltid "snakket om det». Vi er en art som aldri slutter å fortolke tilværelsen, dens smerte, mål og mening. Det ligger imidlertid flere problem i måten vi i dag snakker om livsutfordringer enn at vi snakker om dem. Det har de siste tiår vært en tendens til å snakke om barn og unges sårbarhet fremfor deres robusthet. Generasjonen som vokser opp nå, har fått høre at alt fra peanøttsmør til fremmede menn kan være farlig, noe vi som overlevde 70- og 80-tallet, stort sett ikke fikk vite. Den oppvoksende generasjonen synes mer avhengig av foreldrene sine i hverdagen enn generasjonen forut. Mange unge studenter som søker hjelp og støtte, synes mer å gjøre det fordi de er uforberedt på livet på egenhånd enn at de oppfyller krav til noen diagnose. Kanskje er foreldrene deres vel så opptatt av prestasjoner som de unge selv er.

Det har, som Madsen også påpeker, dessuten vært en betydelig lekkasje fra traumeog stresspsykologien og inn i hverdagsspråket. Tendensen ser vi tydeligst på amerikanske universitet, hvor unge studenter har krevd «trigger warnings» før forelesere presenterer eksempler fra litteratur som kan vekke emosjonelt ubehag. Vi ser imidlertid samtidig en tendens til at ungdom har fått nok av budskapet om egen sykelighet. Både som lærer og terapeut har jeg ikke kunnet unngå å få med meg den canadiske kliniske psykologen Jordan Petersons popularitet - særlig hos unge menn. Og disse unge mennene har begynt å «snakke om det». Ofte på måter som utfordrer tradisjonelle synspunkt i den alminnelige terapeutiske diskursen, og definitivt på måter som utfordrer den liberale venstresiden - det er helt åpenbart at denne veldig snart trenger sin egen Peterson. Madsen antyder hvordan det er behov for en eksistensiell refleksjon og samtale som et alternativ til den diagnostiserende terapeutiske diskursen. Jeg savner en utdyping av dette momentet. Ungdom trenger samtaler om litteratur og kunst som handler om den andelen av livets smerte og ubehag som ikke skal falle inn under diagnostiske kriterier - og den andelen har gjennom historien aldri vært liten. Kunst åpner for en annen type av skapende undring om hvordan vi mennesker kan forholde oss til at det finnes lidelse i livet. Mennesker i vår tid trenger en psykologi som gir aksept for lidelse uten å ty til det diagnostiske språket, men tvert imot lar oss forstå den som en del av egenarten ved det menneskelige. Mennesker har til alle tider prøvd å utforske mulighetene i livet, ikke bare kollektivt, men også individuelt. Da trengs en psykologi som ikke er låsende og essensialistisk, ikke minst knyttet til lidelsens problem, men også til kjønn, selv-definering og livsvalg. Som Madsen også er inne på - slike alternativer finnes allerede. Men Madsens kritikk etterlater like fullt et spørsmål om hvordan den samtalen om livet som hverken er religiøs, terapeutisk eller politisk, kan være. 


\section{Per Einar Binder}

Et spørsmål å stille seg, som Madsen også antyder på slutten av boken, er hvordan ansvarsfordelingen mellom journalistikk og psykologifag egentlig bør være når det kommer til samtidsdiagnoser som "generasjon prestasjon» og "flink pike». Hvor mye er psykologifaglig psykologisering, og hvor mye er journalistisk personfokus? Jeg har selv mange ganger snakket med journalister som ønsker seg «sjekklister» for ulike typer av plager, og som nærmest ber meg om å si at ungdommen i dag strever mye verre enn før. De fleste av våre psykologkolleger vil nok mene at dagens ungdomsgenerasjon rommer et mangfold som ikke så lett lar seg redusere til generasjonsdiagnoser. Å gå ut og si at «dagens unge strever med mye forskjellig, de har det nok neppe verre enn andre generasjoner, men det er også slik at enhver ny generasjon også har litt andre utfordringer enn generasjonene før", er neppe noe en journalist jubler over. Men det er kanskje sant. Madsen er selv en psykolog som lykkes med å nå frem med et slikt budskap, nettopp ved at han fremfører det som en kritikk av egen profesjon. En selv-kritikk som absolutt er nødvendig. En profesjon som har fått såpass stor definisjonsmakt som psykologien, bør være ydmyk og selvransakende. Det mediekritiske budskapet er imidlertid like viktig.

Det er vanskelig å være annet enn enig $\mathrm{i}$ at "generasjon prestasjon» som generasjonsdiagnose er en klisje. På sett og vis ganske parallelt til det faktum at kun et mindretall av 68-generasjonen egentlig var opprørske 68-ere. Dagens ungdomsgenerasjon er langt mer mangfoldig enn hva diagnosen "generasjon prestasjon» formidler. Samtidig er det slik at klisjeene om både 68-ere og generasjon prestasjon har oppstått av en grunn. De beskriver noen trekk ved sentrale miljø blant sine generasjoners mest ressurssterke. Madsens budskap om hvordan den terapeutiserende diskursen kan eller: innsnevre forståelsen av en generasjon, og dessuten forstyrre fokus på dem som virkelig strever, er viktig og betimelig. Neste steg er å spørre seg - ja, hvilket språk for livets smerte og utfordringer trenger vi nå? 